\title{
Synthesis and Characterization of $\left[\mathrm{Cd}_{8} \mathrm{Cl}_{2} \mathrm{Se}(\mathrm{SePh})_{12}\left(\mathrm{PCy}_{3}\right)_{2}\right] \cdot 2.5 \mathrm{CH}_{3} \mathrm{OH}$
}

\author{
Rafael Stieler, ${ }^{a}$ Fabrício Bublitz, ${ }^{a}$ Robert A. Burrow, ${ }^{a}$ Gelson N. Manzoni de Oliveira, ${ }^{a}$ \\ Marcos A. Villetti, ${ }^{b}$ Marcelo B. Pereira, ${ }^{c}$ Paulo Piquini ${ }^{b}$ and Ernesto S. Lang ${ }^{*, a}$ \\ ${ }^{a}$ Departamento de Química and ${ }^{b}$ Departamento de Física, Universidade Federal de Santa Maria, \\ 97105-900 Santa Maria-RS, Brazil \\ 'Instituto de Física, Universidade Federal do Rio Grande do Sul, \\ 91501-970, Porto Alegre-RS, Brazil
}

\begin{abstract}
Neste artigo estamos apresentando a síntese do composto $\left[\mathrm{Cd}_{8} \mathrm{Cl}_{2}\left(\mu_{4}-\mathrm{Se}\right)\right.$ $\left.(\mathrm{SePh})_{12}\left(\mathrm{PCy}_{3}\right)_{2}\right] \cdot 2.5 \mathrm{CH}_{3} \mathrm{OH}$ pela reação de $\mathrm{Cd}(\mathrm{SePh})_{2}$ com $\mathrm{CdCl}_{2}$ e triciclohexilfosfina em metanol em um reator de aço inoxidável sob condições solvotérmicas a $130{ }^{\circ} \mathrm{C}$. Esse composto corresponde ao último resultado de uma série sistemática de reações e visando ao crescimento de clusters moleculares a partir de $\mathrm{Cd}(\mathrm{SePh})_{2}$ como reagente de partida. A importância desta síntese não está baseada somente nas propriedades do produto preparado, mas também no seu possível uso, por exemplo, no desenvolvimento de novas metodologias via estratégias "bottom up" para a obtenção de clusters a partir de uma mesma classe de reagentes - $\mathrm{M}(\mathrm{ER})_{2}(\mathrm{M}=$ metal, $\mathrm{E}=$ calcogênio, $\mathrm{R}=$ alquil ou aril). $\mathrm{O}$ composto apresentado neste artigo foi caracterizado por difração de raios $\mathrm{X}$ em monocristal, análise elementar, análise termogravimétrica e espectroscopia no UV-Vis. Estes últimos resultados foram correlacionados com dados calculados por DFT, teoria do funcional de densidade.
\end{abstract}

In this article we present the synthesis of the compound $\left[\mathrm{Cd}_{8} \mathrm{Cl}_{2} \mathrm{Se}(\mathrm{SePh})_{12}\left(\mathrm{PCy}_{3}\right)_{2}\right] \cdot 2.5 \mathrm{CH}_{3} \mathrm{OH}$ by the reaction of $\mathrm{Cd}(\mathrm{SePh})_{2}$ with $\mathrm{CdCl}_{2}$ and $\mathrm{PCy}_{3}$ in methanol in a stainless steel sealed reactor under solvothermal conditions at $130{ }^{\circ} \mathrm{C}$. This compound represents the latest result of our systematic work on the growth of molecular clusters from $\mathrm{Cd}(\mathrm{SePh})_{2}$ as starting material. Their importance is based not only on the properties of the new compounds, but also by their possible use, for example, in the development of new methods via a "bottom up" strategy to obtain different clusters from single components like $\mathrm{M}(\mathrm{ER})_{2}(\mathrm{M}=$ metal, $\mathrm{E}=$ chalcogen, $\mathrm{R}=$ alkyl or aryl $)$. The title compound was characterized by single crystal X-ray diffractometry, elemental analysis, thermogravimetrical analysis and the UV-Vis spectroscopy. These results were correlated with data calculated by DFT, density functional theory.

Keywords: cadmium(II) complexes, selenium, tellurium, clusters

\section{Introduction}

Organylchalcogen groups bound to metal atoms to generate nanoclusters have become increasingly important due to their potential as semiconductors, among other materials and biological applications. ${ }^{1-4}$ The unique optical and electronic properties inherent to these "quantumconfined particles" (quantum-dots) have been attributed to modifications of the electronic structure - depending upon the particle size - which lead to very different structures than those found in molecular solids or bulk materials. ${ }^{5-7}$

\footnotetext{
*e-mail: eslang@quimica.ufsm.br
}

Our search for new metalchalcogen-containing building blocks is of great interest for many reasons, principally because the variable size of the blocks produces tunable optoeletronic properties of the bulk products, ${ }^{8-10}$ This emerging field - super lattices of crystalline chalcogenides links two traditional, but distinct, areas of research: chalcogenide clusters and reticular materials. ${ }^{11-19}$

Some authors have proposed alternative ways for the development of metal-chalcogenide clusters. Steigerwald and co-workers ${ }^{20-23}$ have demonstrated the utility of trialkylphosphine tellurides $\left(\mathrm{R}_{3} \mathrm{P}=\mathrm{Te}\right)$ as a source of soluble " $\mathrm{Te}(0)$ " to form numerous metal-telluride polynuclear complexes. Corrigan ${ }^{24}$ and Fenske ${ }^{25-27}$ have introduced 
condensation reactions of phosphine-stabilized coppertellurolate clusters for the generation of higher nuclearity complexes,$^{24}$ as well as the use of arylselenolate ligands to stabilize copper-selenide and silver-selenide clusters. ${ }^{24-27}$ Mercury selenide and telluride cluster compounds and their conversions have been studied by Eichhöfer et al. ${ }^{19,28}$ in order to extend optical investigation to group 12-16 (IIb-VI) cluster molecules.

Given our interest in the organochalcogenolate chemistry, we have investigated the reactions of $\mathrm{M}(\mathrm{EPh})_{2}{ }^{29}$ with $\mathrm{MX}_{2}(\mathrm{M}=\mathrm{Hg}, \mathrm{Cd} ; \mathrm{E}=\mathrm{Se}, \mathrm{Te} ; \mathrm{X}=\mathrm{Cl}, \mathrm{Br}, \mathrm{I})$ in coordinating solvents. We have already reported some results about the influence of ligands, coordinating solvents and reaction stoichiometry in the size and stereochemistry of different cluster compounds. ${ }^{30-37}$ Our studies have been extended to investigate new synthetic routes to produce either binary or ternary clusters, such as the reactions of $\mathrm{Hg}(\mathrm{TePh})_{2}$ with $\mathrm{M}^{\prime}$-salts $\left(\mathrm{M}^{\prime}=\mathrm{Ag}^{\mathrm{I}}, \mathrm{Co}^{\mathrm{II}}, \mathrm{Ni}^{\mathrm{II}}\right)$, stabilized by phosphines $\left(\mathrm{PPh}_{3}\right.$ or $\left.\mathrm{P}\left(\mathrm{CH}_{3}\right)_{2} \mathrm{Ph}\right)$ and pyridine. ${ }^{38-40}$

More recently we have found out that a critical step to develop new clusters under controlled conditions is the adequate understanding of the processes which lead to the stabilization and isolation of species like PhEMX $(\mathrm{M}=\mathrm{Cd}$, $\mathrm{Hg} ; \mathrm{E}=\mathrm{Se}, \mathrm{Te} ; \mathrm{X}=\mathrm{Cl}, \mathrm{Br}$, I). In order to demonstrate these procedures and to extend the applicability of this methodology to further examples, we reported the preparation and the structural characterization of a series of cluster molecules

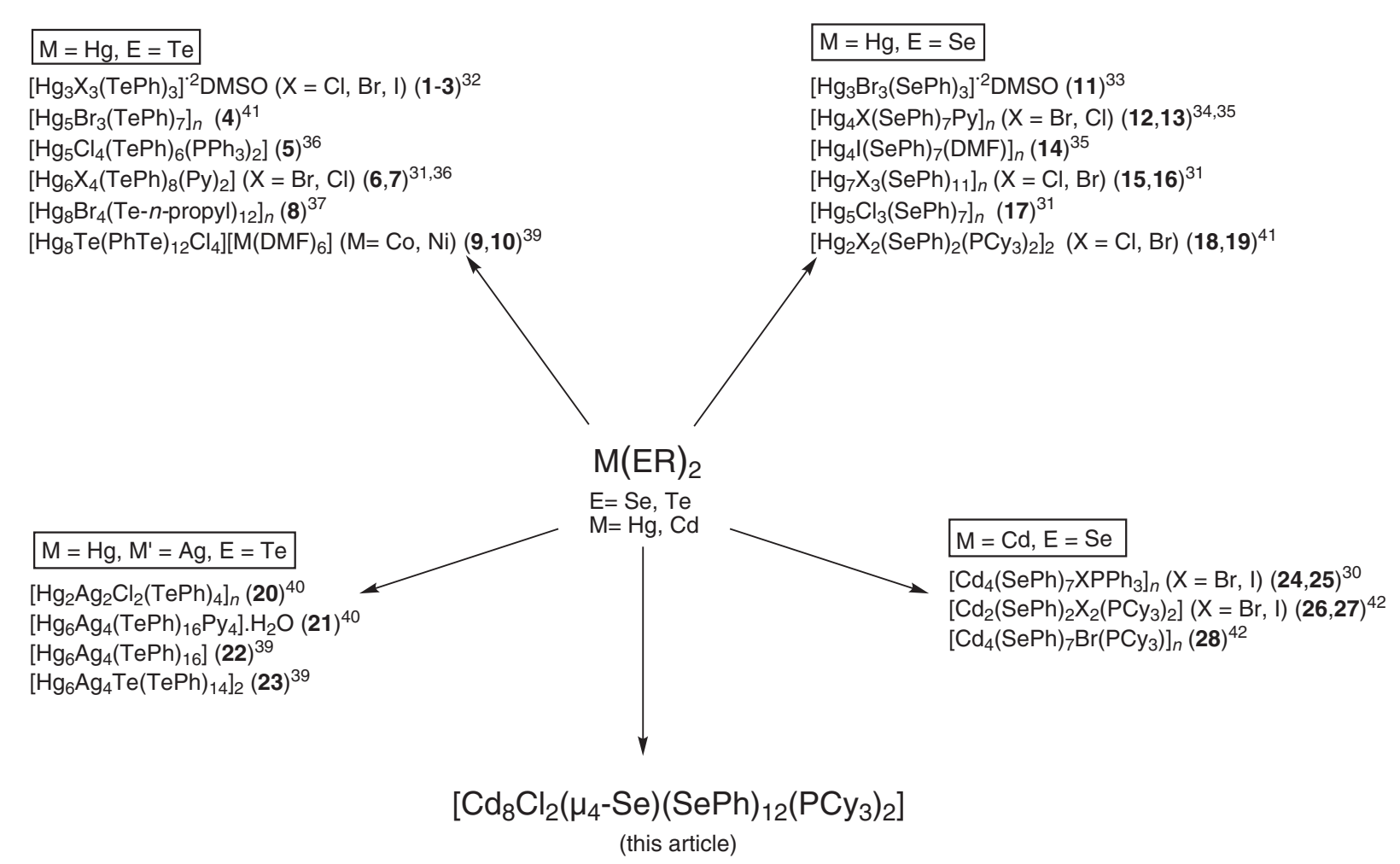

$\left[\mathrm{Cd}_{4}(\mathrm{SePh})_{7} \mathrm{XPPh}_{3}\right]_{n}(\mathrm{X}=\mathrm{Cl}, \mathrm{Br})^{30}\left[\mathrm{Hg}_{2} \mathrm{X}_{2}(\mathrm{SePh})_{2}\left(\mathrm{PCy}_{3}\right)_{2}\right]$ $(\mathrm{X}=\mathrm{Cl}, \mathrm{Br}){ }^{41}\left[\mathrm{Cd}_{2}(\mathrm{SePh}){ }_{2} \mathrm{X}_{2}\left(\mathrm{PCy}_{3}\right)_{2}\right]\left(\mathrm{X}=\mathrm{Br}, \mathrm{I} ; \mathrm{PCy}_{3}=\right.$ tricyclohexylphosphine), ${ }^{42}$ as well as the polymeric cluster $\left[\left\{\mathrm{Hg}_{5} \mathrm{Br}_{3}(\mathrm{TePh})_{7}\right\}_{n}\right]^{41}$ and $\left[\mathrm{Cd}_{4}(\mathrm{SePh})_{7} \mathrm{Br}\left(\mathrm{PCy}_{3}\right)\right] n\left(\mathrm{PCy}_{3}=\right.$ tricyclohexylphosphine). ${ }^{42}$

Finally, with the aim to expand the applicability of new synthetic routes to attain larger clusters, as well as to contribute to the knowledge on the properties and structural features of new materials based in our previous experience (an overview about our previous results is presented in Scheme 1), we describe in this work the synthesis, the structural characterization and the electronic (UV-Vis) spectra of the new cluster $\left[\mathrm{Cd}_{8} \mathrm{Cl}_{2} \mathrm{Se}(\mathrm{SePh})_{12}\left(\mathrm{PCy}_{3}\right)_{2}\right]$.

\section{Experimental}

\section{Materials and measurements}

$\mathrm{CdCl}_{2} \cdot \mathrm{H}_{2} \mathrm{O}, \mathrm{PCy}_{3}$ and other analytical grade reagents and solvents were obtained commercially (Aldrich or Sigma) and used without further purification. $\mathrm{Cd}(\mathrm{SePh})_{2}$ was prepared according to literature procedure. ${ }^{43}$ Elemental analyses (CHN) were carried out with a Perkin-Elmer 2400 analyzer. Infrared spectra were measured on a Bruker Tensor 27 mid-IR spectrometer. Melting points were determined on a Microquímica MQAPF-301 melting point apparatus and are uncorrected.

Scheme 1. 


\section{Crystal structure determinations}

A Bruker CCD X8 Kappa APEX II diffractometer operated using graphite monochromator and Mo-K $\alpha$ radiation $(\lambda=0.71073 \AA$ ) was used for the X-ray structure analyses. The molecular crystal structure of $\left[\mathrm{Cd}_{8} \mathrm{Cl}_{2} \mathrm{Se}-\right.$ $\left.(\mathrm{SePh})_{12}\left(\mathrm{PCy}_{3}\right)_{2}\right] \cdot 2.5 \mathrm{CH}_{3} \mathrm{OH}$ was solved by direct methods with SHELXS. ${ }^{44}$ The final structure was refined with SHELXL ${ }^{44}$ with anisotropic displacement parameters for all non-hydrogen atoms; hydrogen atoms were refined isotropically as riding atoms at their theoretical ideal positions. Additional electron density was localized in voids (367 $\AA^{3}$ total potential solvent accessible volume) summing to $57 \mathrm{e}^{-}$, corresponding to approximately three molecules of the solvent, methanol, per unit cell. This residual electron density was removed using the SQUEEZE routine in PLATON. ${ }^{45}$ More detailed information about the structure determinations is given in Table 1.

\section{Thermogravimetric analyses}

Thermogravimetric measurement was carried out on a Shimadzu DTG-60 device. The experiment was performed in the temperature range from 25 to $600{ }^{\circ} \mathrm{C}$ at heating rates of $10{ }^{\circ} \mathrm{C} \mathrm{min}^{-1}$. The average sample size was $10 \mathrm{mg}$ and

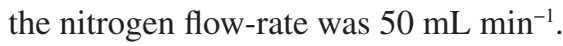

\section{$U V$-Vis spectroscopy}

UV-Vis absorption spectra were recorded on a Varian CARY 50-BIO spectrometer. Solid state diffuse reflectance measurements were carried out on a Varian CARY 5000 spectrometer with a diffuse reflectance accessory.

\section{Preparation of $\left[\mathrm{Cd}_{8} \mathrm{Cl}_{2} \mathrm{Se}(\mathrm{SePh})_{12}\left(\mathrm{PCy}_{3}\right)_{2}\right] \cdot 2.5 \mathrm{CH}_{3} \mathrm{OH}$}

A mixture of $64 \mathrm{mg}(0.15 \mathrm{mmol})$ of $\mathrm{Cd}(\mathrm{SePh})_{2}, 20 \mathrm{mg}$ $(0.1 \mathrm{mmol})$ of $\mathrm{CdCl}_{2} \cdot \mathrm{H}_{2} \mathrm{O}$ and $56 \mathrm{mg}(0.2 \mathrm{mmol})$ of $\mathrm{PCy}_{3}$, in $8 \mathrm{~mL}$ of methanol was heated at $130^{\circ} \mathrm{C}$ for $1 \mathrm{~h}$ in a $12 \mathrm{~mL}$ stainless steel sealed reactor. Thereafter the reactor was cooled down slowly to room temperature (over $6 \mathrm{~h}$ ). Colorless crystals were obtained and were separated by hand from the powdered material. Yield: $42 \mathrm{mg}(0.012 \mathrm{mmol}), 56 \%$ based on $\mathrm{Cd}(\mathrm{SePh})_{2}$. Colorless crystalline substance. Elemental analysis for $\left[\mathrm{Cd}_{8} \mathrm{Cl}_{2} \mathrm{Se}-(\mathrm{SePh})_{12}\left(\mathrm{PCy}_{3}\right)_{2}\right] \cdot 2.5 \mathrm{CH}_{3} \mathrm{OH}$ (Found: $\mathrm{C}$, 37.97; $\mathrm{H}, 3.81$. Calc. for $\mathrm{C}_{110.5} \mathrm{H}_{136} \mathrm{Cl}_{2} \mathrm{Cd}_{8} \mathrm{P}_{2} \mathrm{Se}_{13} \mathrm{O}_{2.5}$ : C, 37.25; H, 3.85\%. mp 164-166 ${ }^{\circ} \mathrm{C}$. IR (KBr): 3051 [ $\left.\mathrm{v}_{\mathrm{s}}(\mathrm{C}-\mathrm{H})\right]$; $2928\left[\mathrm{v}_{\mathrm{as}}\left(\mathrm{CH}_{2}\right)\right] ; 2851\left[\mathrm{v}_{\mathrm{s}}\left(\mathrm{CH}_{2}\right)\right] ; 1574,1471,1443$ $\left[\mathrm{v}_{\mathrm{s}}(\mathrm{C}=\mathrm{C})\right] ; 1068,1021\left[\delta_{\text {ip }}(\mathrm{C}=\mathrm{C}-\mathrm{H})\right] ; 739\left[\delta_{\text {op }}(\mathrm{C}=\mathrm{C}-\mathrm{C})\right], 694$ $\left[\delta_{\text {ip }}(\mathrm{C}=\mathrm{C}-\mathrm{H}) ; 468\left[\delta_{\mathrm{op}}(\mathrm{C}=\mathrm{C}-\mathrm{C})\right] \mathrm{cm}^{-1}\left(\delta_{\mathrm{ip}}\right.\right.$ and $\delta_{\mathrm{op}}$ correspond to in-plane and out-of-plane bendings).

\section{Computational details}

$A b$ initio calculations based on the density functional theory (DFT) have been performed using the GAMESS package. ${ }^{46}$ The hybrid B3LYP functional has been employed to describe the exchange and correlation interactions. ${ }^{47}$ The core electrons are represented by the Stevens-BashKrauss compact effective core potentials (ECP) ${ }^{48}$ which includes relativistic effects for the elements in the third and four rows of the periodic table, while the valence electrons are described by split valence Gaussian basis sets specifically created to accompany the ECPs, which have the following contraction schemes for the studied elements: C (31,31), P(31,31), Se(41,41), $\mathrm{Cl}(4211,4211,411)$, and $\mathrm{Cd}(4211,4211,411)$. The hydrogen atoms are described by an unscaled $-31 \mathrm{G}$ basis set. The geometry of the $\left[\mathrm{Cd}_{8} \mathrm{Cl}_{2} \mathrm{Se}(\mathrm{SePh})_{12}\left(\mathrm{PCy}_{3}\right)_{2}\right] \cdot 2.5 \mathrm{CH}_{3} \mathrm{OH}$ cluster was the one given by the $\mathrm{X}$-ray analysis, i.e., no geometry optimization has been performed. The time-dependent DFT (TD-DFT) was employed to obtain the UV-Visible singlet-singlet electronic transitions. ${ }^{49,50}$ The molecular orbitals and the UV-Visible spectra were obtained by using the Chemcraft package. ${ }^{51,52}$

\section{Results and Discussion}

\section{Syntheses}

The synthesis of metal organochalcogenolate complexes with $\mathrm{M}(\mathrm{ER})_{2}$ and $\mathrm{M}^{\prime}{ }^{(+\mathrm{n})} \mathrm{X}_{\mathrm{n}}\left(\mathrm{M}=\mathrm{Hg} ; \mathrm{M}^{\prime}=\mathrm{Hg}, \mathrm{Ag}\right.$; $\mathrm{E}=\mathrm{Se}, \mathrm{Te}, \mathrm{X}=$ halogen, $\mathrm{NO}_{3} ; \mathrm{R}=$ alkyl and aryl ) offers a powerful route for the production of binary and ternary clusters. ${ }^{30-42}$ We have explored these reactions with $\mathrm{Hg}(\mathrm{ER})_{2}$ in coordinating solvents to prepare a series of $\mathrm{Hg}$-Te, $\mathrm{Hg}$-Se and $\mathrm{Ag}-\mathrm{Te}-\mathrm{Hg}$ clusters (see compounds 1-23 in Scheme 1). Recently, $\mathrm{Cd}(\mathrm{SePh})_{2}$ has been also used in the formation of some cadmium organochalcogenolate complexes $\left[\mathrm{Cd}_{4}(\mathrm{SePh})_{7} \mathrm{XPPh}_{3}\right]_{n}(\mathrm{X}=$ $\mathrm{Cl}, \mathrm{Br})^{30}$ and $\left[\mathrm{Cd}_{2}(\mathrm{SePh})_{2} \mathrm{X}_{2}\left(\mathrm{PCy}_{3}\right)_{2}\right]\left(\mathrm{X}=\mathrm{Br}, \mathrm{I} ; \mathrm{PCy}_{3}=\right.$ tricyclohexylphosphine $)^{42}$ under solvothermal conditions (stainless steel sealed reactor at $130{ }^{\circ} \mathrm{C}$ ). Solvothermal synthesis was useful for the growth of crystals suitable for X-ray structure determination since the crystals grow slowly over the course of hours to days. The reaction of $\mathrm{Cd}(\mathrm{SePh})_{2}$ with $\mathrm{CdCl}_{2} \cdot \mathrm{H}_{2} \mathrm{O}$ and $\mathrm{PCy}_{3}$ in methanol in a 1.5:1:2 molar ratio produces colourless crystals of the compound $\left[\mathrm{Cd}_{8} \mathrm{Cl}_{2} \mathrm{Se}(\mathrm{SePh})_{12}\left(\mathrm{PCy}_{3}\right)_{2}\right] \cdot 2.5 \mathrm{CH}_{3} \mathrm{OH}$ in a good yield (equation 1). If we compare the molar fraction of $\mathrm{Cd}(\mathrm{SePh})_{2}: \mathrm{CdX}_{2}: \mathrm{PR}_{3}$ used before, ${ }^{30,42}$ an increase in the molar fraction of the $\mathrm{Cd}(\mathrm{SePh})_{2}$ results in the corresponding increase of the clusters size. 


$$
\begin{aligned}
7 \mathrm{Cd}(\mathrm{SePh})_{2}+ & \mathrm{CdCl}_{2}+2 \mathrm{PCy}_{3} \rightarrow \\
& {\left[\mathrm{Cd}_{8} \mathrm{Cl}_{2} \mathrm{Se}(\mathrm{SePh})_{12}\left(\mathrm{PCy}_{3}\right)_{2}\right]+\mathrm{Se}(\mathrm{Ph})_{2}(1) }
\end{aligned}
$$

The structure of the cluster $\left[\mathrm{Cd}_{8} \mathrm{Cl}_{2} \mathrm{Se}(\mathrm{SePh})_{12}\left(\mathrm{PCy}_{3}\right)_{2}\right]$ was confirmed by X-ray crystallographic analysis. An ORTEP view of this cluster is presented in Figure 1. The presence of $\mathrm{SePh}_{2}$ also formed in this reaction was not confirmed, but it is in accordance to the theoretical stoichiometric formation of the title compound presented in equation 1 and is well supported by earlier investigations where $\mathrm{Cd}(\mathrm{SePh})_{2}$ was used as a single source to obtain $\mathrm{CdSe}$ and $\mathrm{SePh}_{2}{ }^{53,54}$

\section{Crystal structure}

The X-ray crystal data and the experimental conditions for the analysis of the molecular cluster $\left[\mathrm{Cd}_{8} \mathrm{Cl}_{2}\left(\mu_{4}-\mathrm{Se}\right)\right.$ $\left.(\mathrm{SePh})_{12}\left(\mathrm{PCy}_{3}\right)_{2}\right]$ are given in Table 1 and selected bond distances and angles are presented in Table S1 (Supplementary Information, SI). Figure 1 shows the ORTEP drawing of the title compound with the thermal ellipsoids at the 50\% probability level; the solvate molecules are not shown. The crystal structure determination shows a $367 \AA^{3}$ void in the unit cell, in which additional diffuse electron density was found. No peaks were found in the Fourier synthesis map so SQUEEZE was used to estimate and remove this electron density. A total of $57 \mathrm{e}^{-}$were found and removed. Given that the crystallization was done in methanol, we estimate that there are approximately three molecules of the solvent per unit cell (corresponding to $58 \mathrm{e}^{-}$) in the void. Since there are two molecules per cell, there are 1.5 methanol solvate molecules per molecule in the void. In the crystal structure, with the addition of the one localized solvate molecule per cluster molecule, for each cluster molecule there are a total of 2.5 methanol solvate molecules per cluster molecule. This final formula, $\left[\mathrm{Cd}_{8} \mathrm{Cl}_{2}\left(\mu_{4}-\mathrm{Se}\right)(\mathrm{SePh})_{12}\left(\mathrm{PCy}_{3}\right)_{2}\right] \cdot 2.5 \mathrm{CH}_{3} \mathrm{OH}$ is used throughout this article.

Figure 2 represents the $\left[\mathrm{Cd}_{8} \mathrm{Cl}_{2}\left(\mu_{4}-\mathrm{Se}\right) \mathrm{Se}_{12} \mathrm{P}_{2}\right]$ cluster core as a section of the total molecular structure. A central selenium atom $\left(\mu_{4}-\mathrm{Se} 13\right)$ is tetrahedral surrounded by four cadmium atoms $(\mathrm{Cd} 2, \mathrm{Cd} 3, \mathrm{Cd} 4, \mathrm{Cd} 6)$. Each of these four inner cadmium atoms are bound by three $\mu_{2}-\mathrm{SePh}^{-}$ ligands to four outer cadmium atoms, which also form a tetrahedron, see Figure 3. Additionally, two of the four outer cadmium atoms $(\mathrm{Cd} 5, \mathrm{Cd} 7)$ are bound to chloride ligands $(\mathrm{Cl1}, \mathrm{Cl} 2)$ and the last two cadmium atoms $(\mathrm{Cd} 1$, $\mathrm{Cd} 8)$ are linked to the phosphorus atoms $(\mathrm{P} 1, \mathrm{P} 2)$ of two $\mathrm{PCy}_{3}$ ligands. If selenium atoms are also considered the cage forms a distorted icosahedron as shown in Figure 4. The central core $\left[\mathrm{Cd}_{8}\left(\mu_{4}-\mathrm{Se}\right) \mathrm{Se}_{12}\right]$ of this cluster can be compared with the series of cadmium organochalcogenolate
Table 1. Crystallographic data, data collection procedure, structure

\begin{tabular}{|c|c|}
\hline Empirical formula & $\mathrm{C}_{110.5} \mathrm{H}_{136} \mathrm{Cl}_{2} \mathrm{O}_{2.5} \mathrm{P}_{2} \mathrm{Se}_{13} \mathrm{Cd}_{8}$ \\
\hline Formula weight, $\mathrm{M}$ & 3562.71 \\
\hline Temperature, $\mathrm{T}(\mathrm{K})$ & $293(2)$ \\
\hline Wavelength $(\AA) /$ radiation & $0.71073 / \mathrm{MoK} \alpha$ \\
\hline Crystal system & Triclinic \\
\hline Space group & $P \overline{1}$ \\
\hline \multicolumn{2}{|l|}{ Unit cell dimensions } \\
\hline$a(\AA)$ & 14.9861(3) \\
\hline$b(\AA)$ & $15.1997(3)$ \\
\hline$c(\AA)$ & $30.4974(5)$ \\
\hline$\alpha\left(^{\circ}\right)$ & $93.869(1)$ \\
\hline$\beta\left({ }^{\circ}\right)$ & $103.418(1)$ \\
\hline$\gamma\left({ }^{\circ}\right)$ & $111.585(1)$ \\
\hline Volume, $\mathrm{V}\left(\mathrm{nm}^{3}\right)$ & $6193.0(2)$ \\
\hline$Z$ & 2 \\
\hline Density calculated $\left(\mathrm{Mg} / \mathrm{m}^{3}\right)$ & 1.911 \\
\hline Absorption coefficient $\left(\mathrm{mm}^{-1}\right)$ & 5.280 \\
\hline $\mathrm{F}(000)$ & 3418 \\
\hline Crystal size $\left(\mathrm{mm}^{3}\right)$ & $0.25 \times 0.22 \times 0.19$ \\
\hline $\begin{array}{l}\text { Method / } \theta \text { Range for data } \\
\text { collection }\left({ }^{\circ}\right)\end{array}$ & $\varphi$ and $\omega$ scans / 1.51 to 26.4 \\
\hline Limiting indices $(h, k, l)$ & $-18 \leq h \leq 18,-19 \leq k \leq 15,-38 \leq l \leq 34$ \\
\hline Reflections collected & 96727 \\
\hline Reflections unique/ $\mathrm{R}_{\text {int }}$ & $25026\left[\mathrm{R}_{i n t}=0.0381\right]$ \\
\hline Completeness to theta & $98.5 \%\left(26.40^{\circ}\right)$ \\
\hline Data/restraints/param. & $25026 / 666 / 1166$ \\
\hline Absorption correction & Gaussian \\
\hline Min. and max. transmission & 0.534 and 0.757 \\
\hline Refinement method & Full-matrix least-squares on $F^{2}$ \\
\hline Hydrogen treatment & constr. \\
\hline Final $R$ indices $[I>2 \sigma(I)]$ & $\begin{array}{l}\mathrm{R}_{1}=0.0435 \\
\mathrm{wR}_{2}=0.1066\end{array}$ \\
\hline $\mathrm{R}$ indices (all data) & $\begin{array}{l}\mathrm{R}_{1}=0.0700 \\
\mathrm{wR}_{2}=0.11138\end{array}$ \\
\hline Goodness-of-fit on $F^{2}$ & 1.078 \\
\hline Largest diff. peak and & 1.804 and -1.264 \\
\hline
\end{tabular}
determination and refinement for $\left[\mathrm{Cd}_{8} \mathrm{Cl}_{2}\left(\mu_{4}-\mathrm{Se}\right)(\mathrm{SePh})_{12}\left(\mathrm{PCy}_{3}\right)_{2}\right] \cdot 2.5 \mathrm{CH}_{3} \mathrm{OH}$

hole $\left(\mathrm{e} \AA^{-3}\right)$

Full-matrix least-squares on $F^{2} . \mathrm{w}=1 /\left[\mathrm{s}^{2}\left(\mathrm{Fo}^{2}\right)+(0.0527 \mathrm{P})^{2}+9.4001 \mathrm{P}\right]$ where $\mathrm{P}=\left(\mathrm{Fo}^{2}+2 \mathrm{Fc}^{2}\right) / 3$.

nanoclusters $\left[\mathrm{Cd}_{17} \mathrm{Se}_{4}(\mathrm{SePh})_{24}\left(\mathrm{PPh}_{3}\right)_{4}\right]\left[\mathrm{Cd}_{8} \mathrm{Se}(\mathrm{SePh})_{12} \mathrm{Cl}_{4}\right]$, $\left[\mathrm{Cd}(\mathrm{dmf})_{6}\right]\left[\mathrm{Cd}_{8}(\mathrm{SePh})_{12} \mathrm{Cl}_{4}\right],\left[\mathrm{Cd}_{8} \mathrm{Se}(\mathrm{SePh})_{14}\left(\mathrm{PPh}_{3}\right)_{2}\right]$, $\left[\mathrm{Cd}_{8} \mathrm{Se}(\mathrm{SePh})_{14}(\mathrm{dmf})_{3}\right]$ and $\left[\mathrm{Cd}_{8} \mathrm{Te}(\mathrm{TePh})_{14}\left(\mathrm{PEt}_{3}\right)_{3}\right]$ presented by Behrens and Fenske. ${ }^{55}$

\section{Thermogravimetric analysis}

Figure 5 shows the thermal decomposition of the compound $\left[\mathrm{Cd}_{8} \mathrm{Cl}_{2}\left(\mu_{4}-\mathrm{Se}\right)(\mathrm{SePh})_{12}\left(\mathrm{PCy}_{3}\right)_{2}\right] \cdot 2.5 \mathrm{CH}_{3} \mathrm{OH}$ 


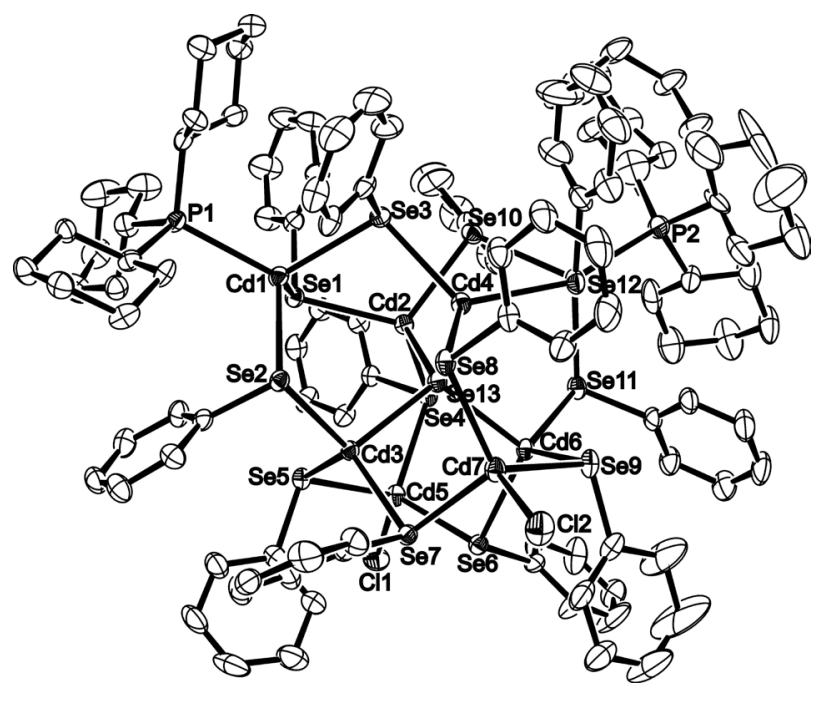

Figure 1. An ORTEP view of $\left[\mathrm{Cd}_{8} \mathrm{Cl}_{2}\left(\mu_{4}-\mathrm{Se}\right)(\mathrm{SePh})_{12}\left(\mathrm{PCy}_{3}\right)_{2}\right]$ with the thermal ellipsoids at the $50 \%$ probability level. The labeling scheme used for the phenyl rings and the hydrogen atoms is omitted for clarity. The $\mathrm{CH}_{3} \mathrm{OH}$ molecule is not shown also for reasons of clarity.

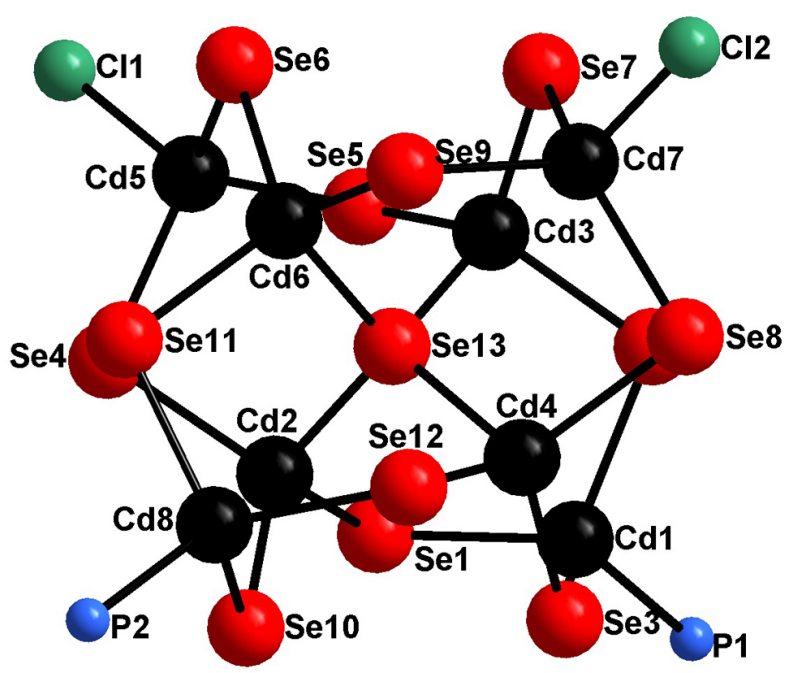

Figure 2. The cluster core as a section of the molecular structure of $\left[\mathrm{Cd}_{8} \mathrm{Cl}_{2}\left(\mu_{4}-\mathrm{Se}\right)(\mathrm{SePh})_{12}\left(\mathrm{PCy}_{3}\right)_{2}\right]$.

as monitored by TGA in inert atmosphere (nitrogen). Thermogravimetric analysis (TGA) of the cluster in a dynamic nitrogen flow shows that the thermal decomposition in the range of $25-600{ }^{\circ} \mathrm{C}$ occurs in three successive steps. The first mass loss $(0.8 \%)$, which occurs between 25 and $100{ }^{\circ} \mathrm{C}$, agrees with the theoretical value $(0.9 \%)$ for the loss of one methanol solvate molecule. The extra half methanol solvate molecule (see the Crystal structure section) was not found in the TGA analysis and likely was spontaneously lost during sample preparation or with just the nitrogen flow due to its much weaker association in the crystal lattice. The second weight loss $(54.4 \%)$ is observed in a two-step process occurring

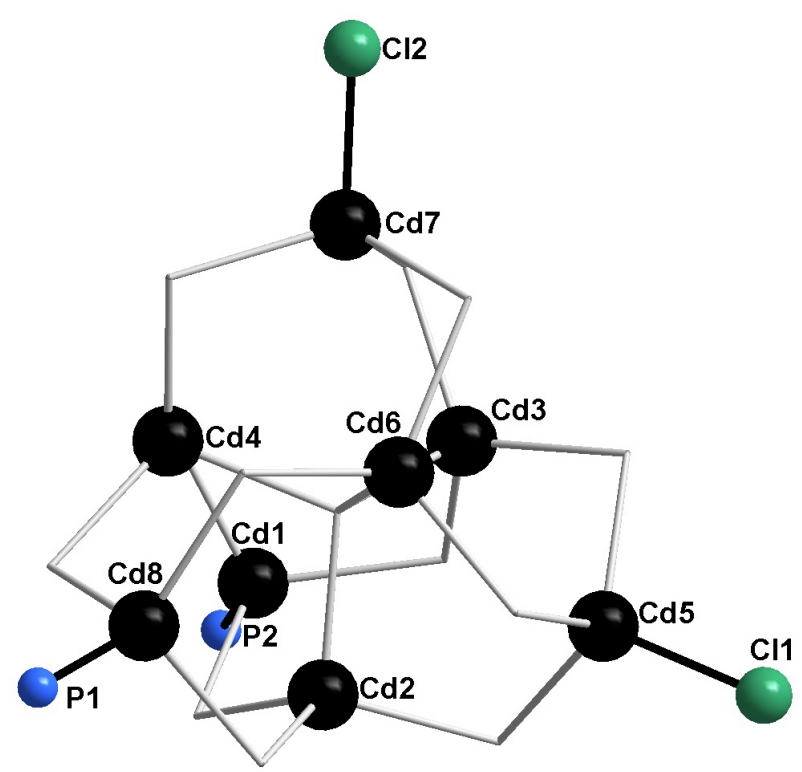

Figure 3. Structure of the cluster core $\left[\mathrm{Cd}_{8} \mathrm{Cl}_{2}\left(\mu_{4}-\mathrm{Se}\right) \mathrm{Se}_{12} \mathrm{P}_{2}\right]$ enhancing the cadmium atoms.

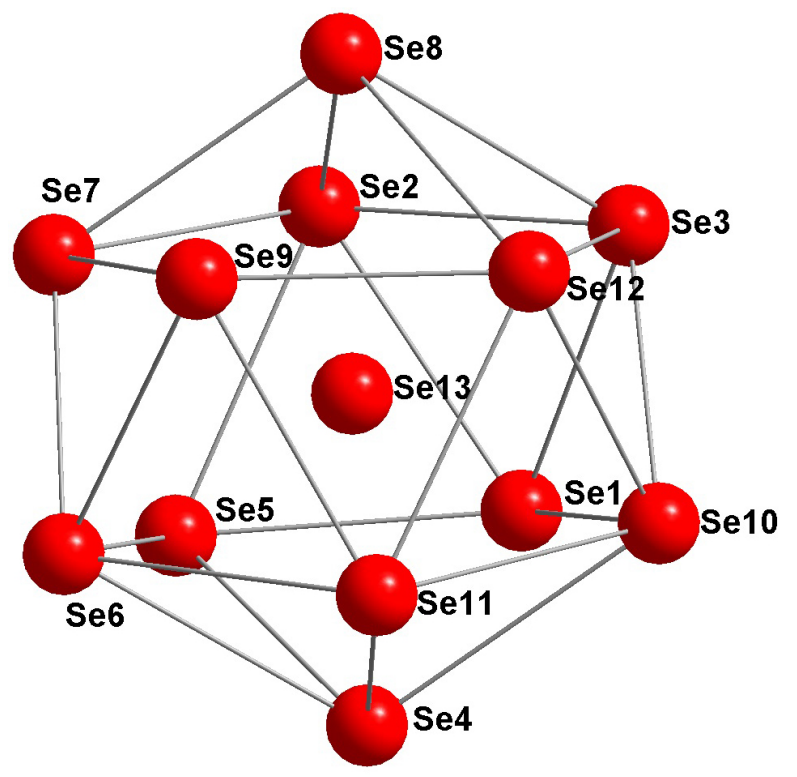

Figure 4. The selenium atoms together form a distorted icosahedron around $\mathrm{Se} 13$ atom.

between 100 and $420^{\circ} \mathrm{C}$, and this suggests that $2 \mathrm{PCy}_{3}$ and $6 \mathrm{SePh}_{2}$ are cleaved, with a theoretical weight loss of $55.7 \%$. The thermogravimetric data agree with the X-ray diffraction results for the molecular structure of the compound, and is similar to the clusters $\left[\mathrm{Cd}_{4}(\mathrm{SePh})_{7}\left(\mathrm{PPh}_{3}\right) \mathrm{X}\right]_{n}(\mathrm{X}=\mathrm{Cl}, \mathrm{Br})$ which we have investigated previously. ${ }^{30}$

\section{$U V$-Vis spectroscopy}

Figure 6 displays the UV-Vis absorption spectrum of $\left[\mathrm{Cd}_{8} \mathrm{Cl}_{2}\left(\mu_{4}-\mathrm{Se}\right)(\mathrm{SePh})_{12}\left(\mathrm{PCy}_{3}\right)_{2}\right]$ as a nujol mull at 


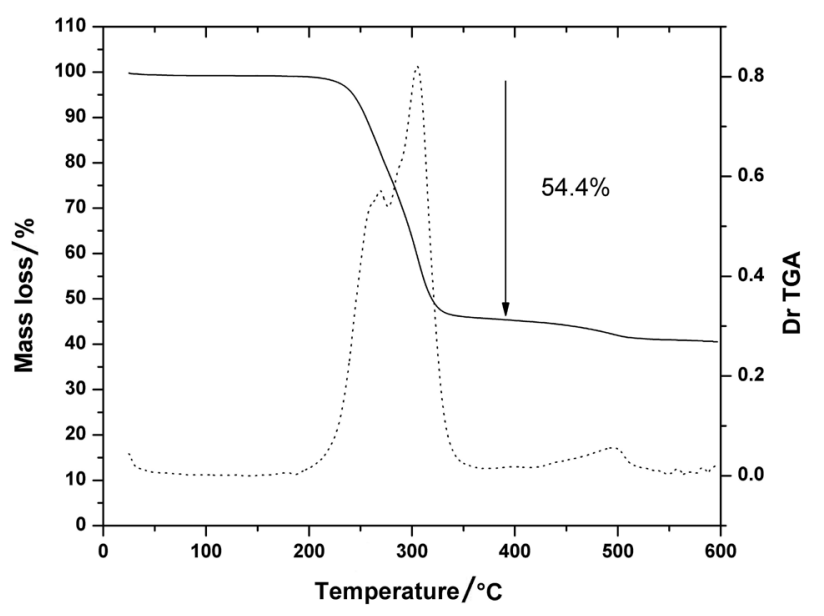

Figure 5. Thermogravimetric measurement was performed in the temperature range from 25 to $600{ }^{\circ} \mathrm{C}$ at heating rates of $10{ }^{\circ} \mathrm{C} \mathrm{min}-1$ for the compound $\left[\mathrm{Cd}_{8} \mathrm{Cl}_{2}\left(\mu_{4}-\mathrm{Se}\right)(\mathrm{SePh})_{12}\left(\mathrm{PCy}_{3}\right)_{2}\right] \cdot 2.5 \mathrm{CH}_{3} \mathrm{OH}$.

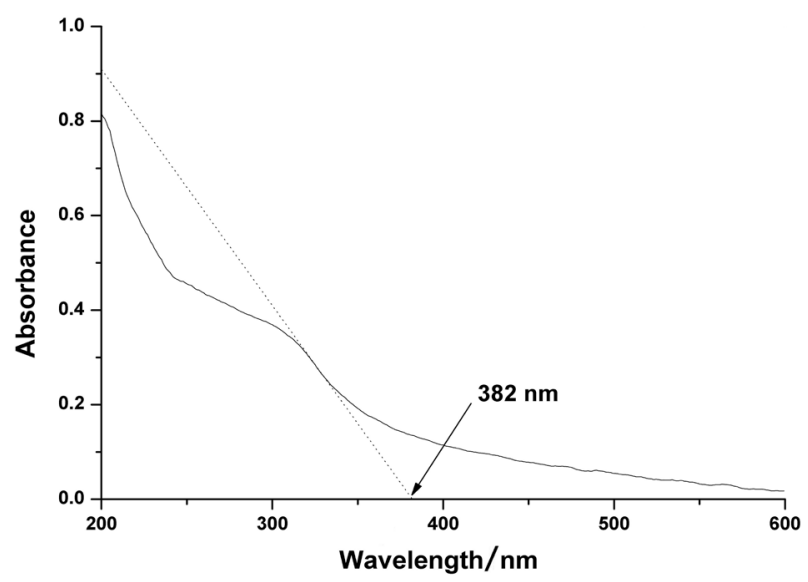

Figure 6. UV-Vis absorption spectrum of $\left[\mathrm{Cd}_{8} \mathrm{Cl}_{2}\left(\mu_{4}-\mathrm{Se}\right)(\mathrm{SePh})_{12}\left(\mathrm{PCy}_{3}\right)_{2}\right]$ as a nujol mull at room temperature. The absorption wavelength for the band gap was calculated by laying the tangent line through the inflection point of the first increase of the curve according to Runge and Gross. ${ }^{49}$

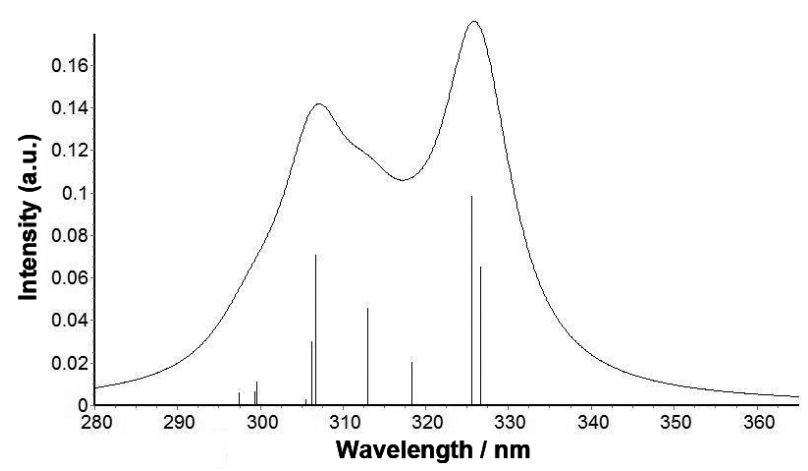

Figure 7. Calculated oscillator strength $v s$. wavelength, $\lambda$, for the $\left[\mathrm{Cd}_{8} \mathrm{Cl}_{2} \mathrm{Se}(\mathrm{SePh})_{12}\left(\mathrm{PCy}_{3}\right)_{2}\right]$ molecule, showing the total spectrum as well as its decomposition in terms of individual electronic transitions. Each peak in the spectrum is represented by a lorentzian function with a $5 \mathrm{~nm}$ broadening. room temperature. The absorption wavelength for the HOMO-LUMO gap was calculated by laying a tangent line through the inflection point of the first increase of the curve, as described previously by Fenske $e t$ al. ${ }^{56}$ The optical gap was calculated considering the intersection point of the tangent line with the abscissa and the estimated HOMO-LUMO gap found is $3.25 \mathrm{eV}(382 \mathrm{~nm})$.

The lowest energy band in the absorption spectrum can be rationalized as originating from ligand-to-metal charge transfer (LMCT) involving the transitions $\mathrm{Se}(4 \mathrm{p}) \rightarrow \mathrm{Cd}(5 \mathrm{~s})$. The solid state diffuse reflectance measurements were performed in the UV-Visible wavelength range (200 to $700 \mathrm{~nm}$ ), as shown in Figure S1 (SI). The spectrum of the cluster exhibits a shoulder between 380 to $400 \mathrm{~nm}$, which corresponds to the beginning of the cluster absorption band (energy range of 3.27 to $3.10 \mathrm{eV}$ ). These energy values and the obtained in nujol mull are typical optical band gaps values in the solid state for similar transition metal chalcogenides, and are in good agreement with data in the literature. ${ }^{9,56,57}$

The optical spectrum was calculated with timedependent DFT. The TD-DFT is currently one of the most popular approaches to calculate electronic excitation spectra due to its accuracy and computational efficiency. It has been successfully applied to a wide range of molecules. There are special cases, however, where it is known to fail in correctly describing the electronic spectra, as in the long-range charge-transfer transitions ${ }^{58}$ Also, states that are dominated by double excitations are completely missing. An analysis of the performance of TD-DFT for the prediction of electronic transitions can be seen in reference 59. In our specific case, where the studied cluster includes heavy atoms like $\mathrm{Cd}$ and $\mathrm{Se}$, it would be desirable to include the spin-orbit coupling, in order to consider the relativistic effects in the description of the valence states. We have, however, neglected the spinorbit coupling in our calculations, since it would increase the computational effort required to perform by a large amount. The calculated electronic absorption spectrum is shown in Figure 7, comprising the ten first singlet-singlet excitations. The first peak in the spectrum has two main contributions, one at $3.79 \mathrm{eV}(326.79 \mathrm{~nm})$, due a (HOMO)(LUMO) excitation, and another at $3.81 \mathrm{eV}(325.65 \mathrm{~nm})$, resulting from a (HOMO-1)-(LUMO) transition. This last transition has a greater contribution than the (HOMO)(LUMO) one, as can be seen in Figure 7. The HOMOLUMO transition has ligand to metal charge transfer (LMCT) character occurring from the p-like orbitals of the Se atoms to the s-orbitals of the $\mathrm{Cd}$ atoms, with minor contributions from sp-like orbitals of Se atoms, as shown in Figures 8(a) and (b), respectively. The third, fourth and fifth excitations, occurring at $3.89 \mathrm{eV}(318.35 \mathrm{~nm}), 3.96 \mathrm{eV}$ 
(313.04 $\mathrm{nm})$, and $4.04 \mathrm{eV}(306.72 \mathrm{~nm})$, are the result from single excitations from the (HOMO-2), (HOMO-3), and (HOMO-4) orbitals to LUMO, respectively. These transitions are responsible for the three main peaks at lower wavelengths in the spectrum. An analysis of the (HOMO-2), (HOMO-3), and (HOMO-4) levels show that they are composed mainly from p-like orbitals of the Se atoms, with contributions from p-like orbitals of the $\mathrm{Cl}$ atoms. The peak at $c a .305 \mathrm{~nm}$ has also a contribution from a (HOMO)-(LUMO+1) transition at $4.05 \mathrm{eV}$ $(306.24 \mathrm{~nm})$. The last four (the seventh to tenth excitations) calculated transitions contribute to a peak at $c a .300 \mathrm{~nm}$. The discrepancy between the calculated and experimental values for the energy (wavelength) of the first electronic transition can be related to some factors. It is known that the TD-DFT calculations do not take into account the electronic relaxation following the electronic excitations. The possible electronic relaxation effects (change of the orbitals after a electronic transition), will reduce the energy of the electronic transition. Also, in our calculations we have taken the geometry directly from the X-ray diffraction experiments (as commented previously). Thus, geometry relaxations could still improve the TD-DFT results, leading to predictions closer to the experimental values.

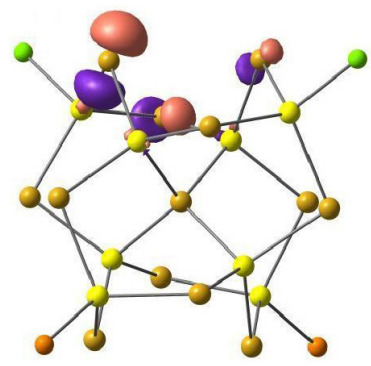

(a)

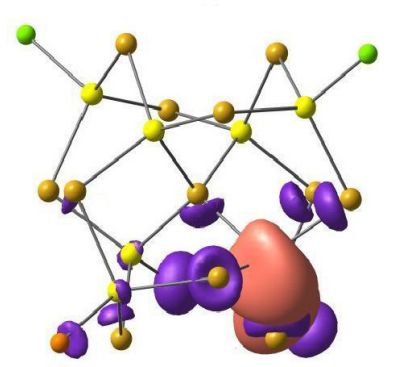

(b)
Figure 8. Wavefunctions associated with (a) HOMO, and (b) LUMO orbitals of the $\left[\mathrm{Cd}_{8} \mathrm{Cl}_{2} \mathrm{Se}(\mathrm{SePh})_{12}\left(\mathrm{PCy}_{3}\right)_{2}\right]$ molecule. The light brown, yellow, green, and orange filled spheres represent the $\mathrm{Se}, \mathrm{Cd}, \mathrm{Cl}$, and $\mathrm{P}$ atoms, respectively (see Figure 2 for comparison).

\section{Conclusions}

The experimental results confirm that $\mathrm{Cd}(\mathrm{SePh})_{2}$ and $\mathrm{Hg}(\mathrm{ER})_{2}(\mathrm{E}=\mathrm{Se}, \mathrm{Te})$ are valuable precursors for the preparation of small cluster molecules and clusters (see Scheme 1) and represents, in principle, an alternative for many reagents used with these purposes. ${ }^{5,56}$ Their importance is based not only on the properties of the new compounds, but by their possible use as a example of the development of new methodologies via a "bottom up" strategy to obtain different clusters from single components like $\mathrm{M}(\mathrm{ER})_{2}(\mathrm{M}=$ metal, $\mathrm{E}=$ chalcogen, $\mathrm{R}=$ alkyl or aryl). Since these methods in general can also be applied to the synthons of the general formula $\mathrm{M}(\mathrm{ER})_{n}$, for which the examples $\mathrm{M}=\mathrm{Mg}, \mathrm{Bi}$, Ga, In, Sn, Sb, Zn, Cd, Hg, Au, Yb, Zr, Hf; E = S, Se, Te; $\mathrm{R}=$ aryl, alkyl, have been reported, ${ }^{29}$ we can also predict that a systematic methodology for the synthesis of binary and ternary clusters should be possible. ${ }^{30-42}$

The formation of the final product - small clusters (26, $\mathbf{2 7}$ ), one-dimensional chains $(\mathbf{2 4}, \mathbf{2 5}, \mathbf{2 8})$, or large clusters depends on the reactivity of the synthon used. The greater is the reactivity of the synthon, the larger the resulting cluster. There are, however, other variables that must be considered as a whole in the growth process of clusters and nanoparticles: stoichiometric proportions of the reagents, solvent, time of reaction, temperature, and the presence (or not) of secondary ligands. All these factors can affect the growth of the compounds, i.e., whether small or bulk, polycyclic clusters will be the final products.

The cluster-molecules represent an ultimate molecular limit of the bulk semiconductors in the structural sense and were also found to exhibit some optical and electronic properties that can be related to the properties of the semiconductors. The core CdSe structure of the molecular cluster $\left[\mathrm{Cd}_{8} \mathrm{Cl}_{2}\left(\mu_{4}-\mathrm{Se}\right)(\mathrm{SePh})_{12}\left(\mathrm{PCy}_{3}\right)_{2}\right]$ is similar to the $\mathrm{CdSe}$ wurtzite structure, thus the core can be considered as nanometrically sized particles of bulk CdSe. The lowest energy band $3.25 \mathrm{eV}(382 \mathrm{~nm})$ in the absorption spectrum can be rationalized as originating from ligandto-metal charge transfer (LMCT) involving the transition $\operatorname{Se}(4 p) \rightarrow \operatorname{Cd}(5 s){ }^{60}$

\section{Supplementary Information}

Table S1 (selected bond lengths and angles) and Figure S1 (solid state diffuse reflectance measurements) can be found as supplementary data available free of charge at http://jbcs.sbq.org.br, as PDF file. CCDC 768444 contains the supplementary crystallographic data for $\left[\mathrm{Cd}_{8} \mathrm{Cl}_{2}\left(\mu_{4}-\mathrm{Se}\right)(\mathrm{SePh})_{12}\left(\mathrm{PCy}_{3}\right)_{2}\right] \cdot 2.5 \mathrm{CH}_{3} \mathrm{OH}$. These data can be obtained free of charge via http://www.ccdc. cam.ac.uk/conts/retrieving.html, or from the Cambridge Crystallographic Data Centre, 12 Union Road, Cambridge CB2 1EZ, UK; fax: (44) 1223-336-033; or e-mail: deposit@ccdc.cam.ac.uk.

\section{Acknowledgments}

This work was supported with funds from MCT/CNPq and FAPERGS/PRONEX 10/0005-1. CNPq is thanked for scholarships (R. S. and F. B.). The quantum chemistry calculations were performed on the computational facilities of CENAPAD/Campinas. 


\section{References}

1. Klein, D. L.; Roth, R.; Lim, A. K. L.; Alivisatos, A. P.; McEuen, P. L.; Nature 1997, 389, 699.

2. Radloff, C.; Moran, C. E.; Jackson, J. B.; Halas N. J.; Reed, M. A.; Lee T.; Molecular Nanoelectronics, Reed, M. A.; Lee, T. eds., Yale University: USA, 2003.

3. Michalet, X.; Kapanidis, A.N.; Laurence, T.; Pinaud, F.; Doose, S.; Pflughoefft, M.; Weiss, S.; Ann. Rev. Biophys. Biomol. Struct. 2003, 32, 161.

4. Bruchez, M.; Moronne, M.; Gin, P.; Weiss, S.; Alivisatos, A.; Science 1998, 281, 2013.

5. Alivisatos, A. P.; J. Phys. Chem. 1996, 100, 13226.

6. Efros, A. L.; Rosen, M.; Annu. Rev. Mater. Sci. 2000, 30, 475.

7. DeGroot, M. W.; Cockburn, M. W.; Workentin, M. S.; Corrigan, J. F.; Inorg. Chem. 2001, 40, 4678.

8. Tran, D. T. T.; Beltran, L. M. C.; Kowalchuk, C. M.; Trefiak, N. R.; J. Taylor, N. J.; Corrigan, J. F.; Inorg. Chem. 2002, 41, 5693.

9. De Groot, M. W.; J. Taylor, N. J.; Corrigan, J. F.; Inorg. Chem. 2005, 44, 5447.

10. Henkel, G.; Krebs, B.; Chem. Rev. 2004, 104, 801.

11. Li, H.; Kim, J.; Groy, T. L.; O’Keeffe, M.; Yaghi, O. M.; J. Am. Chem. Soc. 2001, 123, 4867.

12. Wang, C.; Bu, X.; Zheng, N.; Feng, P.; J. Am. Chem. Soc. 2002, 124, 10268.

13. Feng, P.; Bu, X.; Zheng, N.; Acc. Chem. Res. 2005, 38, 293.

14. Zhang, Q.; Bu, X.; Han, L.; Feng, P.; Inorg. Chem. 2006, 45, 6684 .

15. Wang, C.; Bu, X.; Zheng, N.; Feng, P.; J. Am. Chem. Soc. 2007, 129,8412 .

16. Vossmeyer, T.; Reck, G.; Katsikas, L.; Haupt, E. T. K.; Schulz, B.; Weller, H.; Science 1995, 267, 1476.

17. Vossmeyer, T.; Reck, G.; Schulz, B.; Katsikas, L.; Weller, H.; J. Am. Chem. Soc. 1995, 117, 12881.

18. Rogach, A.; Kershaw, S.; Burt, M.; Harrison, M.; Eychmüller, A.; Weller, H.; Adv. Mater. 1999, 11, 552.

19. Eichhöfer, A.; Deglmann, P.; Eur. J. Inorg. Chem. 2004, 349.

20. Steigerwald, M. L.; Polyhedron 1994, 13, 1245.

21. Steigerwald, M. L.; Siegrist, T.; S. Stuczynski, M.; Inorg. Chem. 1991, 30, 4940.

22. Brennan, J. G.; Siegrist, T.; Stuczynski, S. M.; Steigerwald, M. L.; J. Am. Chem. Soc. 1990, 112, 9233.

23. Brennan, J. G.; Siegrist, T.; Stuczynski, S. M.; Steigerwald, M. L.; J. Am. Chem. Soc. 1989, 111, 9240.

24. Corrigan, J. F.; Fenske, D.; Angew. Chem., Int Ed. 1997, 36, 1981.

25. Bettenhausen, M.; Eichöfer, A.; Fenske, D.; Semmelmann, M. Z.; Z. Anorg. Allg. Chem. 1999, 625, 593.

26. Zhu, N.; Fenske, D.; J. Chem. Soc., Dalton Trans. 1999, 1067.
27. Fenske, D.; Zhu, N.; Langetepe, T.; Angew. Chem., Int. Ed. 1998, 37, 2640.

28. Eichhöfer, A.; Tröster, E.; Eur. J. Inorg. Chem. 2002, 2253.

29. Sadekov, I. D.; Zakharov, A. V.; Russ. Chem. Rev. 1999, 68, 909.

30. Lang, E. S.; Burrow, R. A.; Stieler, R.; Villetti, M. A.; J. Organomet. Chem. 2009, 694, 3039.

31. Lang, E. S.; de Oliveira, G. N. M.; Tirloni, B.; Lago, A. B.; Vázquez-López, E. M.; J. Clust. Sci. 2009, 20, 467.

32. Lang, E. S.; Zan, R. A.; Gatto, C. C.; Burrow, R. A.; VázquezLópez, E. M.; Eur. J. Inorg. Chem. 2002, 2, 331.

33. Lang, E. S.; de Oliveira, G. M.; Dias, M. M.; Santos, S. S.; Abram, U.; Vázquez-López, E. M.; Z. Anorg. Allg. Chem. 2004, 630, 462.

34. Casagrande, G. A.; Lang, E. S.; de Oliveira, G. M.; Hörner, M.; Broch, F.; Inorg. Chim. Acta 2007, 360, 1776.

35. Lang, E. S.; Tirloni, B.; de Oliveira, G. N. M.; Villetti, M. A.; Inorg. Chim. Acta 2009, 362, 3114.

36. Lang, E. S.; de Oliveira, G. N. M.; Tirloni, B.; Villetti, M. A.; J. Clust. Sci. 2008, 19, 459.

37. Lang, E. S.; Peppe, C.; Zan, R.A.; Abram, U.; Vázquez-López, E. M.; Krumm, B.; Ruscitti, O. P.; Z. Anorg. Allg. Chem. 2002, $628,2815$.

38. Lang, E. S.; de Oliveira, G. M.; Back, D. F.; Santos, S. S.; Z. Anorg. Allg. Chem. 2004, 630, 730.

39. Back, D. F.; de Oliveira, G. N. M.; Burrow, R. A.; Castellano, E. E.; Abram, U.; Lang, E. S.; Inorg. Chem. 2007, 46, 2356.

40. Back, D. F.; de Oliveira, G. N. M.; Lang, E. S.; Polyhedron 2008, 27, 3255.

41. Tirloni, B.; Back, D. F.; Burrow, R. A.; de Oliveira, G. N. M.; Villetti, M. A.; Lang, E. S.; J. Braz. Chem. Soc. 2010, 21, 1230.

42. Lang, E. S.; Stieler, R.; de Oliveira, G. N. M.; Polyhedron 2010 , 29, 1760.

43. Anjali, K. S.; Vittal, J. J.; Inorg. Chem. Commun. 2000, 3, 708.

44. Sheldrick, G. M.; Acta Cryst. 2008, A64, 112.

45. Spek, A. L.; J. Appl. Cryst. 2003, 36, 7.

46. Schmidt, M. W.; Baldridge, K. K.; Boatz, J. A.; Elbert, S. T.; Gordon, M. S.; Jensen, J. H.; Koseki, S.; Matsunaga, N.; Nguyen, K. A.; Su, S. J.; Windus, T. L.; Dupuis, M.; Montgomery, J. A.; J. Comput. Chem. 1993, 14, 1347.

47. Becke, A. D.; J. Chem. Phys. 1993, 98, 1372; Lee, C.; Yang, W.; Parr, R. G.; Phys. Rev. B 1988, 37, 785.

48. Stevens, W. J.; Basch, H.; Krauss, M.; J. Chem. Phys. 1984, 81, 6026; Stevens, W. J.; Krauss, M.; Basch, H.; Jasien, P. G.; Can. J. Chem. 1992, 70, 612.

49. Runge, E.; Gross, E. K. U.; Phys. Rev. Lett. 1984, 52, 997.

50. Casida, M. E. In Recent Advances in Density Functional Methods; Chong, D. P., ed., World Scientific: Singapore, 1995.

51. Bode, B. M.; Gordon, M. S.; J. Mol. Graphics Mod. 1998, 16, 133. 
52. Allouche, A. R.; J. Comput. Chem. 2010, DOI: 10.1002/ jcc.21600 (ChemCraft; http://www.chemcraftprog.com).

53. Cumberland, S. L.; Hanif, K. M.; Javier, A.; Khitrov, G. A.; Strouse, G. F.; Woessner, S. M.; Yun, C. S.; Chem. Mater. 2002, 14, 1576.

54. De Groot, M. W.; Rösner, H.; Corrigan, J. F.; Chem. Eur. J. 2006, 12, 1547.

55. Behrens, S.; Fenske, D.; Phys. Chem. 1997, 101, 1588.

56. Fu, M.-L.; Fenske, D.; Weinert, B.; Fuhr, O.; Eur. J. Inorg. Chem. 2010, 1098.
57. Eichkorn, K.; Ahlrichs R.; Chem. Phys. Let. 1998, 288, 235.

58. Dreuw, A.; Head-Gordon, M.; Chem. Rev. 2005, 105, 4009.

59. Neese, F.; J. Biol. Inorg. Chem. 2006, 11, 702.

60. Eichhöfer, A.; Aharoni, A.; Banin, U.; Z. Anorg. Allg. Chem. 2002, 628, 2415.

Submitted: August 4, 2010 Published online: September 10, 2010 


\section{Synthesis and Characterization of $\left[\mathrm{Cd}_{8} \mathrm{Cl}_{2} \mathrm{Se}(\mathrm{SePh})_{12}\left(\mathrm{PCy}_{3}\right)_{2}\right] \cdot 2.5 \mathrm{CH}_{3} \mathrm{OH}$}

\section{Rafael Stieler, ${ }^{a}$ Fabrício Bublitz, ${ }^{a}$ Robert A. Burrow, ${ }^{a}$ Gelson N. Manzoni de Oliveira, ${ }^{a}$ Marcos A. Villetti, ${ }^{b}$ Marcelo B. Pereira, ${ }^{c}$ Paulo Piquini ${ }^{b}$ and Ernesto S. Lang ${ }^{* a}$ \\ ${ }^{a}$ Departamento de Química and ${ }^{b}$ Departamento de Física, Universidade Federal de Santa Maria, 97105-900 Santa Maria-RS, Brazil}

'Instituto de Física, Universidade Federal do Rio Grande do Sul, 91501-970, Porto Alegre-RS, Brazil

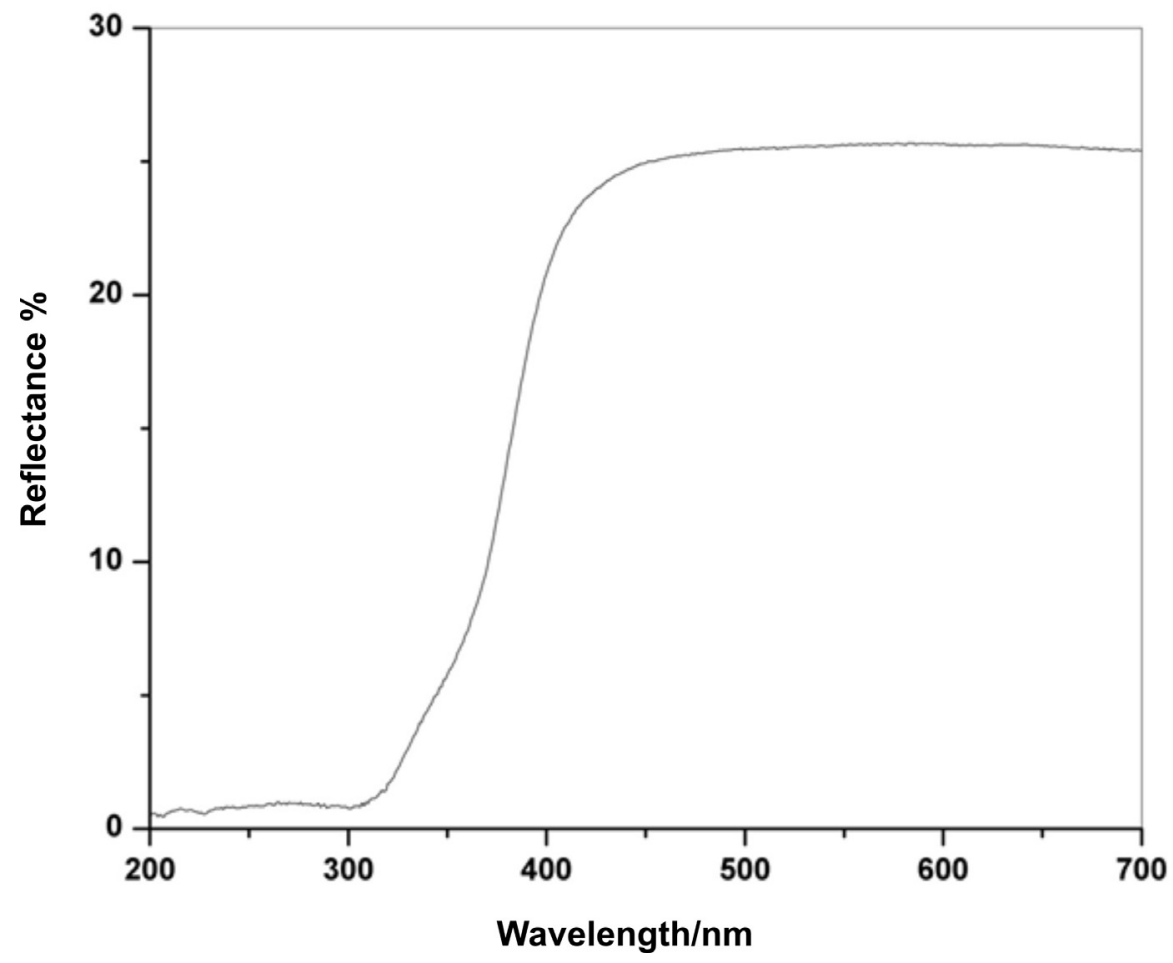

Figure S1. Solid state diffuse reflectance measurements of $\left[\mathrm{Cd}_{8} \mathrm{Cl}_{2}\left(\mu_{4}-\mathrm{Se}\right)(\mathrm{SePh})_{12}\left(\mathrm{PCy}_{3}\right)_{2}\right]$ (UV-Visible wavelength range). 
Table S1. Selected bond lengths $(\AA)$ and angles $\left({ }^{\circ}\right)$ refined from X-ray data for $\left[\mathrm{Cd}_{8} \mathrm{Cl}_{2}\left(\mu_{4}-\mathrm{Se}\right)(\mathrm{SePh})_{12}\left(\mathrm{PCy}_{3}\right)_{2}\right] \cdot 2.5 \mathrm{CH}_{3} \mathrm{OH}$

\begin{tabular}{|c|c|c|c|}
\hline \multicolumn{4}{|l|}{ Bond Lengths } \\
\hline $\mathrm{Se}(1)-\mathrm{Cd}(2)$ & $2.6361(8)$ & $\operatorname{Se}(1)-\operatorname{Cd}(1)$ & $2.6791(8)$ \\
\hline $\operatorname{Se}(2)-C d(3)$ & $2.6247(8)$ & $\operatorname{Se}(2)-\operatorname{Cd}(1)$ & $2.6763(9)$ \\
\hline $\operatorname{Se}(3)-\operatorname{Cd}(4)$ & $2.6408(9)$ & $\operatorname{Se}(3)-\operatorname{Cd}(1)$ & $2.7026(9)$ \\
\hline $\operatorname{Se}(4)-\operatorname{Cd}(2)$ & $2.6320(8)$ & $\operatorname{Se}(4)-\operatorname{Cd}(5)$ & $2.6851(9)$ \\
\hline $\operatorname{Se}(5)-C d(3)$ & $2.6154(9)$ & $\operatorname{Se}(5)-\operatorname{Cd}(5)$ & $2.6358(8)$ \\
\hline $\operatorname{Se}(6)-\operatorname{Cd}(6)$ & $2.6166(9)$ & $\operatorname{Se}(6)-\operatorname{Cd}(5)$ & $2.6624(9)$ \\
\hline $\operatorname{Se}(7)-\operatorname{Cd}(3)$ & $2.6277(9)$ & $\operatorname{Se}(7)-\operatorname{Cd}(7)$ & $2.6583(9)$ \\
\hline $\operatorname{Se}(8)-C d(4)$ & $2.6248(9)$ & $\operatorname{Se}(8)-\operatorname{Cd}(7)$ & $2.6532(9)$ \\
\hline $\operatorname{Se}(9)-\operatorname{Cd}(6)$ & $2.6261(9)$ & $\operatorname{Se}(9)-\operatorname{Cd}(7)$ & $2.6483(9)$ \\
\hline $\operatorname{Se}(10)-C d(2)$ & $2.6461(9)$ & $\operatorname{Se}(10)-\operatorname{Cd}(8)$ & $2.6678(9)$ \\
\hline $\operatorname{Se}(11)-\operatorname{Cd}(6)$ & $2.6400(9)$ & $\operatorname{Se}(11)-\operatorname{Cd}(8)$ & $2.6965(10)$ \\
\hline $\operatorname{Se}(12)-C d(4)$ & $2.6546(8)$ & $\mathrm{Se}(12)-\mathrm{Cd}(8)$ & $2.6741(10)$ \\
\hline $\operatorname{Se}(13)-C d(4)$ & $2.5768(8)$ & $\operatorname{Se}(13)-C d(2)$ & $2.5798(8)$ \\
\hline $\operatorname{Se}(13)-\operatorname{Cd}(3)$ & $2.5891(8)$ & $\operatorname{Se}(13)-\operatorname{Cd}(6)$ & $2.5932(8)$ \\
\hline $\mathrm{P}(2)-\mathrm{Cd}(8)$ & $2.613(2)$ & $\mathrm{P}(1)-\mathrm{Cd}(1)$ & $2.6148(18)$ \\
\hline $\mathrm{Cl}(1)-\mathrm{Cd}(5)$ & $2.458(2)$ & $\mathrm{Cl}(2)-\mathrm{Cd}(7)$ & $2.461(2)$ \\
\hline \multicolumn{4}{|l|}{ Bond Angles } \\
\hline $\mathrm{Cd}(2)-\mathrm{Se}(4)-\mathrm{Cd}(5)$ & $101.40(3)$ & $\mathrm{C}(51)-\mathrm{Se}(5)-\mathrm{Cd}(3)$ & $96.3(2)$ \\
\hline$C(51)-\operatorname{Se}(5)-C d(5)$ & $105.3(2)$ & $\mathrm{Cd}(3)-\mathrm{Se}(5)-\mathrm{Cd}(5)$ & $98.01(3)$ \\
\hline $\mathrm{C}(61)-\operatorname{Se}(6)-\mathrm{Cd}(6)$ & $99.7(2)$ & $\mathrm{C}(61)-\mathrm{Se}(6)-\mathrm{Cd}(5)$ & $103.5(2)$ \\
\hline $\mathrm{Cd}(6)-\operatorname{Se}(6)-\mathrm{Cd}(5)$ & $98.24(3)$ & $\mathrm{Cd}(3)-\mathrm{Se}(7)-\mathrm{Cd}(7)$ & 102.01(3) \\
\hline $\mathrm{C}(81)-\mathrm{Se}(8)-\mathrm{Cd}(4)$ & $97.1(2)$ & $\mathrm{C}(81)-\mathrm{Se}(8)-\mathrm{Cd}(7)$ & $108.1(2)$ \\
\hline $\mathrm{Cd}(4)-\mathrm{Se}(8)-\mathrm{Cd}(7)$ & $96.66(3)$ & $\mathrm{Cd}(6)-\mathrm{Se}(9)-\mathrm{Cd}(7)$ & $96.38(3)$ \\
\hline $\mathrm{Cd}(2)-\mathrm{Se}(10)-\mathrm{Cd}(8)$ & $102.15(3)$ & $\mathrm{Cd}(6)-\mathrm{Se}(11)-\mathrm{Cd}(8)$ & 103.07(3) \\
\hline $\mathrm{Cd}(4)-\mathrm{Se}(12)-\mathrm{Cd}(8)$ & $106.22(3)$ & $\mathrm{Cd}(4)-\mathrm{Se}(13)-\mathrm{Cd}(2)$ & $107.00(3)$ \\
\hline $\mathrm{Cd}(4)-\operatorname{Se}(13)-\mathrm{Cd}(3)$ & $110.15(3)$ & $\mathrm{Cd}(2)-\mathrm{Se}(13)-\mathrm{Cd}(3)$ & $108.00(3)$ \\
\hline $\mathrm{Cd}(4)-\operatorname{Se}(13)-\mathrm{Cd}(6)$ & $112.84(3)$ & $\mathrm{Cd}(2)-\mathrm{Se}(13)-\mathrm{Cd}(6)$ & 111.81(3) \\
\hline $\mathrm{Cd}(3)-\mathrm{Se}(13)-\mathrm{Cd}(6)$ & $106.96(3)$ & $\mathrm{P}(1)-\mathrm{Cd}(1)-\mathrm{Se}(2)$ & $108.18(5)$ \\
\hline $\mathrm{P}(1)-\mathrm{Cd}(1)-\mathrm{Se}(1)$ & $111.49(5)$ & $\operatorname{Se}(2)-\operatorname{Cd}(1)-\operatorname{Se}(1)$ & $111.36(3)$ \\
\hline $\mathrm{P}(1)-\mathrm{Cd}(1)-\mathrm{Se}(3)$ & $116.68(5)$ & $\operatorname{Se}(2)-\operatorname{Cd}(1)-\operatorname{Se}(3)$ & $105.42(3)$ \\
\hline $\operatorname{Se}(1)-\operatorname{Cd}(1)-\operatorname{Se}(3)$ & $103.54(3)$ & $\operatorname{Se}(13)-\operatorname{Cd}(2)-\operatorname{Se}(4)$ & $101.43(3)$ \\
\hline $\mathrm{Se}(13)-\mathrm{Cd}(2)-\mathrm{Se}(1)$ & $108.29(3)$ & $\operatorname{Se}(4)-\mathrm{Cd}(2)-\operatorname{Se}(1)$ & $116.52(3)$ \\
\hline $\operatorname{Se}(13)-\mathrm{Cd}(2)-\operatorname{Se}(10)$ & $102.98(3)$ & $\mathrm{Se}(4)-\mathrm{Cd}(2)-\mathrm{Se}(10)$ & $113.16(3)$ \\
\hline $\operatorname{Se}(1)-\operatorname{Cd}(2)-\operatorname{Se}(10)$ & $112.72(3)$ & $\operatorname{Se}(13)-\mathrm{Cd}(3)-\operatorname{Se}(5)$ & $105.09(3)$ \\
\hline $\operatorname{Se}(13)-\operatorname{Cd}(3)-\operatorname{Se}(2)$ & $103.77(3)$ & $\operatorname{Se}(5)-\operatorname{Cd}(3)-\operatorname{Se}(2)$ & $112.61(3)$ \\
\hline $\operatorname{Se}(13)-\mathrm{Cd}(3)-\operatorname{Se}(7)$ & $100.72(3)$ & $\operatorname{Se}(5)-\operatorname{Cd}(3)-\operatorname{Se}(7)$ & $119.42(3)$ \\
\hline $\operatorname{Se}(2)-\mathrm{Cd}(3)-\mathrm{Se}(7)$ & $112.80(3)$ & $\operatorname{Se}(13)-\mathrm{Cd}(4)-\operatorname{Se}(8)$ & $104.89(3)$ \\
\hline $\operatorname{Se}(13)-C d(4)-\operatorname{Se}(3)$ & $105.29(3)$ & $\operatorname{Se}(8)-C d(4)-\operatorname{Se}(3)$ & $111.80(3)$ \\
\hline $\operatorname{Se}(13)-\mathrm{Cd}(4)-\operatorname{Se}(12)$ & $99.09(3)$ & $\operatorname{Se}(8)-\mathrm{Cd}(4)-\operatorname{Se}(12)$ & $114.69(3)$ \\
\hline $\operatorname{Se}(3)-\mathrm{Cd}(4)-\operatorname{Se}(12)$ & 118.67(3) & $\mathrm{Cl}(1)-\mathrm{Cd}(5)-\mathrm{Se}(5)$ & $110.08(6)$ \\
\hline $\mathrm{Cl}(1)-\mathrm{Cd}(5)-\mathrm{Se}(6)$ & 106.97(6) & $\operatorname{Se}(5)-\operatorname{Cd}(5)-\operatorname{Se}(6)$ & $110.72(3)$ \\
\hline $\mathrm{Cl}(1)-\mathrm{Cd}(5)-\mathrm{Se}(4)$ & $109.33(6)$ & $\operatorname{Se}(5)-\operatorname{Cd}(5)-\operatorname{Se}(4)$ & 107.94(3) \\
\hline $\operatorname{Se}(6)-\operatorname{Cd}(5)-\operatorname{Se}(4)$ & $111.80(3)$ & $\operatorname{Se}(13)-\operatorname{Cd}(6)-\operatorname{Se}(6)$ & $105.10(3)$ \\
\hline $\operatorname{Se}(13)-\mathrm{Cd}(6)-\mathrm{Se}(9)$ & 105.99(3) & $\operatorname{Se}(6)-\operatorname{Cd}(6)-\operatorname{Se}(9)$ & $114.63(3)$ \\
\hline $\operatorname{Se}(13)-\operatorname{Cd}(6)-\operatorname{Se}(11)$ & 101.71(3) & $\operatorname{Se}(6)-\operatorname{Cd}(6)-\operatorname{Se}(11)$ & $113.90(3)$ \\
\hline $\operatorname{Se}(9)-\mathrm{Cd}(6)-\mathrm{Se}(11)$ & $113.84(3)$ & $\mathrm{Cl}(2)-\mathrm{Cd}(7)-\mathrm{Se}(9)$ & $102.32(6)$ \\
\hline $\mathrm{Cl}(2)-\mathrm{Cd}(7)-\mathrm{Se}(8)$ & $107.93(7)$ & $\mathrm{Se}(9)-\mathrm{Cd}(7)-\mathrm{Se}(8)$ & $118.50(3)$ \\
\hline $\mathrm{Cl}(2)-\mathrm{Cd}(7)-\mathrm{Se}(7)$ & $110.50(7)$ & $\operatorname{Se}(9)-\mathrm{Cd}(7)-\operatorname{Se}(7)$ & $108.76(3)$ \\
\hline $\operatorname{Se}(8)-\mathrm{Cd}(7)-\mathrm{Se}(7)$ & $108.59(3)$ & $\mathrm{P}(2)-\mathrm{Cd}(8)-\mathrm{Se}(10)$ & $113.68(6)$ \\
\hline $\mathrm{P}(2)-\mathrm{Cd}(8)-\mathrm{Se}(12)$ & $117.81(8)$ & $\operatorname{Se}(10)-\operatorname{Cd}(8)-\operatorname{Se}(12)$ & $102.39(3)$ \\
\hline $\mathrm{P}(2)-\mathrm{Cd}(8)-\mathrm{Se}(11)$ & $105.78(7)$ & $\operatorname{Se}(10)-\operatorname{Cd}(8)-\operatorname{Se}(11)$ & 109.11(3) \\
\hline $\operatorname{Se}(12)-\mathrm{Cd}(8)-\operatorname{Se}(11)$ & $107.80(3)$ & & \\
\hline
\end{tabular}

